\title{
Intraspecific and interspecific relationships between host size and the abundance of parasitic larval gnathiid isopods on coral reef fishes
}

\author{
Alexandra S. Grutter ${ }^{1, *}$, Robert Poulin ${ }^{2}$ \\ ${ }^{1}$ Department of Parasitology, The University of Queensland, Brisbane, Queensland 4072, Australia \\ ${ }^{2}$ Department of Zoology, University of Otago, PO Box 56, Dunedin, New Zealand
}

\begin{abstract}
Parasitic gnathiid isopod larvae on coral reef teleosts and elasmobranchs were quantified at Lizard and Heron Islands (Great Barrier Reef), and Moreton Bay, Australia. The relationship between gnathiid abundance and host size was examined across and within species. Of the 56 species examined, $70 \%$ had gnathiids, with counts ranging from 1 to 200 per fish and the elasmobranchs having the highest numbers. Pomacentrids rarely had gnathiids. In contrast, most labrids had gnathiids. Gnathiid abundance was positively correlated with host size in the species Chlorurus sordidus, Ctenochaetus striatus, Hemigymnus melapterus, Siganus doliatus, and Thalassoma lunare, but not for Scolopsis bilineatus. Mean gnathiid abundance per host species also correlated with host size across species, even after controlling for the potential confounding effects of uneven sampling effort and host phylogeny. Thus host size explains much of the intraspecific and interspecific variation in gnathiid abundance on fish.
\end{abstract}

KEY WORDS: Gnathiidae - Ectoparasites - Coral reef fish · Host-parasite interactions - Fish size - Great Barrier Reef

\section{INTRODUCTION}

Until recently, there was little evidence that parasites were important in fish cleaning behavior (Losey 1987), however, current studies on the Great Barrier Reef, Australia, show that parasites, in particular gnathiid isopod larvae, play a significant role in cleaning interactions. Ninety percent of the items in the diet of the cleaner wrasse Labroides dimidiatus are gnathiids (Grutter 1997a) and each of these cleaner fish eats on average 1200 parasites per day (Grutter 1996a). Larger gnathiids are also selectively preyed on by this cleaner fish (Grutter 1997b). Most importantly, the high predation rate, relative to the number of gnathiids on fish and their infection rate, suggests that $L$. dimidiatus have an effect on the abundance of

•E-mail: a.grutter@mailbox.uq.edu.au gnathiids on fish (Grutter 1996a). When present in 'large' numbers (Paperna \& Por 1977) and when fish have 'around a hundred' (Mugridge \& Stallybrass 1983), gnathiids can cause fish mortality in captive fish (Paperna \& Por 1977). Gnathiids, in 'numerous numbers', also affect stingrays in the wild, causing destruction and inflammation of the mucosal tissues and a propagation of bacilli (Honma \& Chiba 1991). That cleaner fish may control these potentially deleterious parasites has important implications for understanding the ecological significance of cleaning, as studies to date have been unable to experimentally demonstrate any benefit of cleaning to the host (Youngbluth 1968, Losey 1972, Gorlick et al. 1987, Grutter 1996b, 1997 c). Information on gnathiids, therefore, is needed to understand their role in cleaning.

Research on gnathiids has likely been hindered by their complicated life history. Gnathiids are only parasitic as larvae, feeding on host blood and other fluids, 
and return to the benthos to moult after each of the 3 larval stages (Monod 1926, Upton 1987, Klitgaard 1991). Adults are benthic and do not feed. Because adult males and females are so different from each other, species descriptions are based on males. About one fourth of the 155 gnathiid species described worldwide are from Australia (Cohen \& Poore 1994 and references therein). Of these, 5 have been described from the Great Barrier Reet. Despite the richness of gnathiid species in Australia, little is known of their ecology, particularly of the parasitic stages.

Although information on what fish species are cleaned by Labroides dimidiatus is available (Grutter \& Poulin 1998), it is not known from which fish species these cleaners obtain gnathiids. On the Great Barrier Reef, few fish species have been examined for gnathiids ( 7 species in Grutter 1994, and 2 recorded in Lester \& Sewell 1989). Elsewhere they have been found on a wide variety of tish, ranging from large elasmobranchs in Japan (Honma et al. 1991) to small blennies in England (Davies 1981).

There is evidence that gnathiid abundance is correlated with host size within the labrid species Hemigymnus melapterus (Grutter 1996a) and among 6 other fish species (Grutter 1994). Larger fish with more parasites are cleaned more often and longer (Grutter 1995a). Understanding the relationship between host size and gnathiid abundance may explain variation in gnathiid abundance among fish and provide insight into the role of gnathiids in cleaning behavior. This study quantified the abundance of gnathiids on a wide range of fish species collected at Lizard Island, Heron Island, and Moreton Bay, Australia, and examined the relationship between gnathid abundance and host size both within and among species.

\section{MATERIALS AND METHODS}

Fish collection. Fish were collected from shallow reefs ( 2 to $7 \mathrm{~m}$ ) at Lizard Island $\left(14^{\circ} 40^{\prime} \mathrm{S}, 145^{\circ} 26^{\prime} \mathrm{E}\right.$ ) in October 1991, June and August 1992, January 1993 and October 1994, at Heron Island $\left(23^{\circ} 27^{\prime} \mathrm{S}\right.$, $151^{\circ} 55^{\prime} \mathrm{E}$ ) in June 1993, March and April 1996, and July and August 1996, and at Moreton Bay (Brisbane, Queensland) in May and Jume 1996. Teleost fish were collected by herding one fish at a time into a net and capturing it with a handnet following Grutter (1994. 1995b). Fish were sealed in plastic bags to avoid gnathijd loss during handling and transport. Fish species were selected based on their ease of collection and availability and from as wide a range of families as possible and are therefore not a random sample. Standard length was used as the measure of teleost host size
Elasmobranchs were collected on the reef flat $(0.5$ to $2 \mathrm{~m}$ depth) at Heron Island by herding rays and sharks into a net. Sharks and rays at Heron Island were held in a $4.5 \times 4.5 \mathrm{~m}$ pool for 1 to $5 \mathrm{wk}$ prior to the removal of gnathiids. Rays from Moreton Bay were collected with a commercial twim-otter board trawl. Lengths of sharks are measured as total length. The size of rays was measured along the widest (wings) part of the body. These measurement methods and the one above were chosen because they best estimated the relative sizes of the hosts.

Gnathiid removal. To remove gnathiids, larger fish (>60 mm) (except those collected at Heron Island in March 1996, see below) were soaked in the anaesthetic chloretone for 30 to $60 \mathrm{~min}$ and all liquids were filtered at $57 \mu \mathrm{m}$ (except for some species collected prior to June 1996 for which a $57 \mu \mathrm{m}$ or a $200 \mu \mathrm{m}$ filter was used; see Grutter 1994 for species and filters used). These methods were modified for some of the species due to high mucus loads (Scaridae: the whole fish and gills were scanned using a dissecting microscope) or difficulties in removing all parasites from gills (Hemigymnus melapterus: gills were removed and examined separately) (see Grutter 1994, 1995b for modifications). Relatively small fish species ( $<60 \mathrm{~mm}$ ) were fixed whole and scanned under a microscope for parasites following Grutter (1996b). Parasites and small fish were fixed in $5 \%$ Formalin in seawater.

To reduce processing time when removing gnathiids from fish, gnathiid removal without an anaesthetic bath was tested. Fish collected in March 1996 were rinsed and all fins and gills scraped with the tip of a squirt bottle. All liquids were filtered at $57 \mu \mathrm{m}$. A subset of fish ( 38 individuals from 19 species) was examined under a microscope after the rinse to determine if any gnathiids remained. Only 1 gnathiid was found remaining compared to 31 gnathiids removed, indicating a $3 \%$ loss.

To remove gnathiids from elasmobranchs, fish were pithed and their gills excised and examined for gnathiids with a stereo microscope. The buccal and gill cavities and surface of the fish were also examined. Gnathiids were gently pulled off using forceps. Gnathiid abundances greater than 50 are likely minimum estimates as gnathiids were observed in the bottom of the pool in which the elasmobranchs were held indicating that some gnathiids had left their hosts

Statistical analysis. The relationship between gnathiid abundance and host size was assessed both within and among fish species. For the within-species analyses, data on fishes of the 6 most common species collected at all times were used (Acanthochromis polyacanthus was omitted because it was rarely infected). To determine whether or not to pool data from both locations, the effect of location on abundance was 
tested using analysis of covariance (ANCOVA.) with fish standard length as the covariable. Additional specimens of Hemigymnus melapterus $(n=7)$ collected from similar sites at Lizard Island were included in the analyses to increase the sample size but were not included in other analyses due to their small sample size at each collection time. Simple linear correlation coefficients between host size and gnathiid abundance were computed within each species. Uninfected and infected fish were included in correlation analyses and when calculating mean abundances per species. Abundances were $\log (x+1)$ transformed to meet the assumptions of the above analyses.

For comparative analyses across fish species, fish of the same species were pooled across sampling times and locations. Only species for which at least 3 individuals had been examined at the same location were included. This generated a data set comprising 29 host species that was analyzed using 2 approaches. First, using these 29 species as independent observations, we performed a multiple regression in which mean gnathiid abundance per species was the dependent variable and mean fish size and sample size, i.e. the number of fish examined per species, were the independent variables. All species values were log transformed for the analysis. It was important to control for the effect of sampling effort as a confounding variable because larger samples are more likely to include the rare, heavily-parasitized individuals in a population (see Poulin 1996).

The second comparative analysis controlled for potential phylogenetic influences. Closely related species are more similar than distantly related species; for instance they may harbor similar numbers of gnathiids for the simple reason that they inherited a certain susceptibility to gnathiids from a common ancestor. Related species cannot therefore be treated as statistically independent (Harvey \& Pagel 1991). To remove potential phylogenetic influences, we employed the method of phylogenetically independent contrasts (Felsenstein 1985, Harvey \& Pagel 1991) using the CAIC program, version 2.0 (Purvis \& Rambaut 1994). This approach consists of using a fish phylogeny to derive a set of independent contrasts between sister taxa. The computations were performed on log-transformed data and followed the procedures outlined in Garland et al. (1992) and Pagel (1992). True branch lengths in the phylogeny were not known and we adopted a punctuated model of evolution in the analyses by assigning equal lengths to all branches. This is justified by the inadequacy of methods for assigning arbitrary branch lengths when the phylogeny is not fully resolved (Purvis et al. 1994). The phylogeny of fish is generally poorly resolved. We used the proposed relationships among higher taxa and families of Nelson
(1994). Relationships among contrasts were assessed using correlations and regressions forced through the origin (see Garland et al. 1992 for details and justification). Estimates of gnathiid abundance corrected for sample size were obtained by using the residuals of a regression of contrasts in gnathiid abundance on contrasts in sample size.

The comparative analyses described above were repeated after the exclusion of fish species on which no gnathiids were found. These may be either true cases of zero abundance or cases of extreme underestimation of gnathiid abundance because the samples of these species did not include any fish harboring gnathiids. This reduced the number of species in the analysis from 29 to 20 .

\section{RESULTS}

Gnathiids were common on the fish examined. Descriptions of gnathiids are based on males (Cohen \& Poore 1994), therefore larvae were not identified. Instead, all gnathiid larvae were pooled together (whether belonging to 1 or more species) as members of the same ecological guild. Gnathiids on elasmobranchs were mostly in the gills and buccal cavity and occasionally the anus and skin. On teleosts, gnathiids were found on the gills, buccal cavity, nares, eyes, body surface, and fins. The majority of gnathiids on teleosts left the host after capture and were found in the fluids used to transport fish. This mobility made it difficult to assess their site specificity. In contrast, gnathiids of elasmobranchs were firmly attached to hosts, even after gills were removed.

Seventy percent of the 56 teleost and elasmobranch fish species examined had gnathiids, with abundances ranging from 1 to more than 200 per fish (Tables 1 to 3 ). All 20 families examined, except the Chaetodontidae (butterflyfish) and Synodontidae (lizardfish), had species with gnathiids. Only 1 fish of the latter was examined, however. Pomacentrids rarely had gnathiids and when they did they only had 1 per fish. In contrast, almost all labrid species had gnathiids, with Hemigymnus melapterus having the highest gnathiid abundances per teleost fish at both locations (Tables 1 \& 2). All elasmobranch species had gnathiids (Table 3 ).

Of the fish species examined at Heron Island, $71 \%$ of the 31 teleost species and all 6 elasmobranch species had gnathiids (Tables $1 \& 3$ ). Similarly, $65 \%$ of the 31 teleost species from Lizard Island were infected with gnathiids (Table 2). The 2 elasmobranch species from Moreton Bay also had gnathiids (Table 3). Among the 6 species well represented at both locations, Hemigymnus melapterus, Siganus doliatus and Thalassoma Iunare from Lizard Island had a significantly higher 
Table 1. Abundance of gnathiid isopod larvae on teleost fish sampled in June 1993 and March 1996 at Heron Island Australia. Gnathiid abundances for June 1993 are from Grutter (1994)

\begin{tabular}{|c|c|c|c|c|c|c|c|}
\hline \multirow[t]{2}{*}{ Family } & \multirow[t]{2}{*}{ Species } & \multirow[t]{2}{*}{ Date } & \multicolumn{2}{|c|}{$\begin{array}{l}\text { No. of gnathiids } \\
\text { per fish }\end{array}$} & \multicolumn{2}{|c|}{$\begin{array}{l}\text { Standard length } \\
\text { of host }(\mathrm{cm})\end{array}$} & \multirow[t]{2}{*}{$\mathrm{n}$} \\
\hline & & & Mean & SE & Mean & SE & \\
\hline Acanthuridae & $\begin{array}{l}\text { Acanthurus auranticavus } \\
\text { Ctenochaetus striatus }\end{array}$ & $\begin{array}{l}\text { Mar } 96 \\
\text { Jun } 93\end{array}$ & $\begin{array}{l}4 \\
1.3\end{array}$ & $\overline{0.4}$ & $\begin{array}{l}20.1 \\
13.2\end{array}$ & $-\overline{1.3}$ & $\begin{array}{l}1 \\
6\end{array}$ \\
\hline Balistidae & Sufflamen chrysopterus & Mar 96 & 3 & 2 & 13.8 & 0.4 & 2 \\
\hline Bythitidae & Brosmophyciops pautzkei & Mar 96 & 1 & - & 5 & - & 1 \\
\hline Chaetodontidae & $\begin{array}{l}\text { Chaetodon auriga } \\
\text { Chaetodon lineolatus }\end{array}$ & $\begin{array}{l}\text { Mar } 96 \\
\text { Mar } 96\end{array}$ & $\begin{array}{l}0 \\
0\end{array}$ & $\begin{array}{l}0 \\
0\end{array}$ & $\begin{array}{l}12.9 \\
21.2\end{array}$ & $\begin{array}{l}0.4 \\
4.9\end{array}$ & $\begin{array}{l}3 \\
3\end{array}$ \\
\hline Haemulidae & Diagramma labiosum & Mar 96 & 3.7 & 2 & 26.0 & 3.3 & 3 \\
\hline Labridae & $\begin{array}{l}\text { Cheilinus chlorourus } \\
\text { Choerodon cyanodus } \\
\text { Choerodon fasciatus } \\
\text { Halichoeres marginatus } \\
\text { Hemigymnus fasciatus } \\
\text { Iemigymnus melapterus } \\
\text { H. melapterus } \\
\text { Thalassoma lunare } \\
\text { T. lunare } \\
\text { Thalassoma lutescens }\end{array}$ & $\begin{array}{l}\text { Mar } 96 \\
\text { Mar } 96 \\
\text { Mar } 96 \\
\text { Mar } 96 \\
\text { Mar } 96 \\
\text { Jun } 93 \\
\text { Mar } 96 \\
\text { Jun } 93 \\
\text { Mar } 96 \\
\text { Mar } 96\end{array}$ & $\begin{array}{l}2.5 \\
0.5 \\
1.8 \\
0 \\
2.9 \\
5.3 \\
7.1 \\
1.3 \\
1.9 \\
1.7\end{array}$ & $\begin{array}{l}2.5 \\
0.5 \\
0.9 \\
- \\
1.2 \\
1.3 \\
1.9 \\
0.5 \\
0.9 \\
0.6\end{array}$ & $\begin{array}{l}15.5 \\
25.6 \\
15.2 \\
10.3 \\
12.6 \\
12.7 \\
16.0 \\
12.5 \\
16.1 \\
13.6\end{array}$ & $\begin{array}{l}5.4 \\
2.2 \\
0.6 \\
- \\
0.4 \\
1.9 \\
0.9 \\
0.8 \\
0.9 \\
0.4\end{array}$ & $\begin{array}{r}2 \\
2 \\
4 \\
1 \\
7 \\
8 \\
13 \\
8 \\
15 \\
7\end{array}$ \\
\hline Lutjanidae & $\begin{array}{l}\text { Lutjanus carponotatus } \\
\text { Pterocaesio marri }\end{array}$ & $\begin{array}{l}\text { Miar } 96 \\
\text { Mar } 96\end{array}$ & $\begin{array}{l}0.3 \\
0.3\end{array}$ & $\begin{array}{l}0.3 \\
0.3\end{array}$ & $\begin{array}{l}20.3 \\
12.1\end{array}$ & $\begin{array}{l}0.2 \\
1.5\end{array}$ & $\begin{array}{l}3 \\
4\end{array}$ \\
\hline Nemipteridae & $\begin{array}{l}\text { Scolopsis bilineatus } \\
\text { S. bilineatus }\end{array}$ & $\begin{array}{l}\text { Jun } 93 \\
\text { Mar } 96\end{array}$ & $\begin{array}{l}0.9 \\
0.5\end{array}$ & $\begin{array}{l}0.4 \\
0.2\end{array}$ & $\begin{array}{l}13.2 \\
14.6\end{array}$ & $\begin{array}{l}1.3 \\
0.6\end{array}$ & $\begin{array}{l}8 \\
6\end{array}$ \\
\hline Pomacentridae & $\begin{array}{l}\text { Abudefduf bengalensis } \\
\text { Acanthochromis polyacanthus } \\
\text { Chromis nitida } \\
\text { Dischistodus melanotus } \\
\text { Dischistodus perspicillatus } \\
\text { Neoglyphidodon melas } \\
\text { Pomacentrus amboinensis } \\
\text { Pomacentrus wardi }\end{array}$ & $\begin{array}{l}\text { Mar } 96 \\
\text { Jun } 96 \\
\text { Mar } 96 \\
\text { Mar } 96 \\
\text { Mar } 96 \\
\text { Mar } 96 \\
\text { Mar } 96 \\
\text { Mar } 96\end{array}$ & $\begin{array}{l}0 \\
0 \\
0 \\
0.1 \\
0.25 \\
0.3 \\
0 \\
0\end{array}$ & $\begin{array}{l}0 \\
0 \\
0 \\
0.1 \\
0.25 \\
0.2 \\
0 \\
0\end{array}$ & $\begin{array}{r}11.4 \\
8.6 \\
5.9 \\
9.2 \\
13.0 \\
10.3 \\
6.6 \\
7.3\end{array}$ & $\begin{array}{l}0.3 \\
0.5 \\
0.1 \\
0.3 \\
0.7 \\
0.4 \\
0.2 \\
0.2\end{array}$ & $\begin{array}{r}3 \\
7 \\
3 \\
10 \\
4 \\
12 \\
6 \\
8\end{array}$ \\
\hline Scaridae & $\begin{array}{l}\text { Chlorurus sordidus } \\
\text { C. sordidus } \\
\text { Scarus ghobban } \\
\text { Scarus schlegeli }\end{array}$ & $\begin{array}{l}\text { Jun } 93 \\
\text { Mar } 96 \\
\text { Mar } 96 \\
\text { Mar } 96\end{array}$ & $\begin{array}{l}0 \\
3.75 \\
1 \\
1\end{array}$ & $\begin{array}{l}0 \\
3.75 \\
- \\
-\end{array}$ & $\begin{array}{l}13.6 \\
18.0 \\
31.5 \\
24\end{array}$ & $\begin{array}{l}1.2 \\
1.5 \\
- \\
-\end{array}$ & $\begin{array}{l}9 \\
4 \\
1 \\
1\end{array}$ \\
\hline Siganidae & $\begin{array}{l}\text { Siganus doliatus } \\
\text { S. doliatus }\end{array}$ & $\begin{array}{l}\text { Jun } 96 \\
\text { Mar } 96\end{array}$ & $\begin{array}{l}3.6 \\
0\end{array}$ & $\begin{array}{l}0.9 \\
0\end{array}$ & $\begin{array}{l}16 \\
14.1\end{array}$ & $\begin{array}{l}7 \\
0.2\end{array}$ & $\begin{array}{l}8 \\
2\end{array}$ \\
\hline Synodontidae & Synodus variegatus & Mar 96 & 0 & - & 1.1 .3 & - & 1 \\
\hline
\end{tabular}

gnathiid abundance than conspecifics at Heron Island (Table 4). There were similar trends in gnathiid abundance between locations for Scolopsis bilineatus and Chlorurus sordidus; however, they were not significant ( $\mathrm{p}=0.0530$ and $\mathrm{p}=0.0584$ respectively). In contrast, the abundance of gnathiids on Ctenochaetus striatus did not differ between locations (Table 4).

Because of the above differences between locations, only data from Lizard Island were used to examine the relationship between host size and gnathiid abundance. Within species, gnathiid abundance was positively correlated with host size for Chlorurus sordidus ( $\mathrm{r}=0.560, \mathrm{n}=27, \mathrm{p}=0.002)$, Ctenochaetus striatus $(\mathrm{r}=0.559, \mathrm{n}=26, \mathrm{p}=0.003)$, Hemigymnus melapterus $(r=0.690, n=62, p<0.001)$, Siganus doliatus $(r=0.571$, $\mathrm{n}=29, \mathrm{p}=0.001)$, and Thalassoma lunare $(\mathrm{r}=0.515$, $\mathrm{n}=47, \mathrm{p}<0.001$, but not significant for Scolopsis bilineatus $(\mathrm{r}=0.346, \mathrm{n}=31, \mathrm{p}=0.057)$.

Across species, when treating species as independent observations, the multiple regression model provided a good fit to the variation in gnathiid abundance $\left(\mathrm{r}^{2}=0.545, \mathrm{p}<0.001\right)$ (Fig. 1). Both host size (partial regression coefficient $r=0.748, p<0.001$ ) and sample size (partial regression coefficient $r=0.514, p<0.005$ ) explained a significant portion of the variability. Thus, this analysis suggests that gnathiid abundance in- 
Table 2. Abundance of gnathiid isopod larvae on teleost fish sampled in October 1991, June 1992, August 1992, and January 1993 at Lizard Island, Australia. Gnathiid abundances in June 1992, August 1992, and January 1993 are from Grutter (1994). na: not available

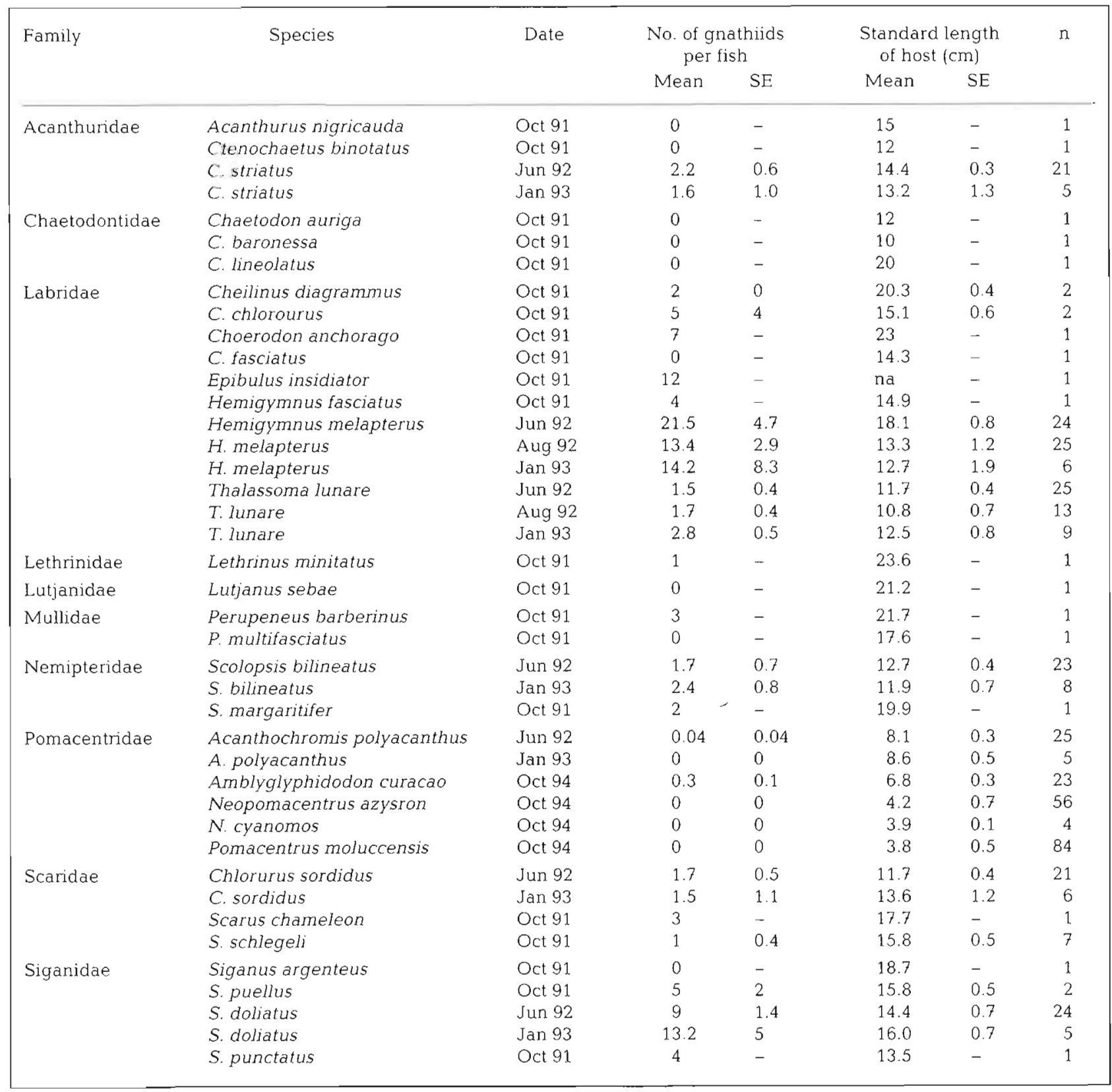

creases with host size, independent of sampling effort. This significant correlation remained in a similar analysis excluding zeros, i.e. uninfected species (host size vs gnathiid abundance, partial regression coefficient $r=0.730, p<0.005$ ).

The phylogeny employed in the comparative analysis using independent contrasts allowed 21 contrasts to be computed. Both fish size $(r=0.399, p>0.05)$ and sample size $(r=0.105, p>0.05)$ correlated positively but not significantly with gnathiid abundance. How- ever, using the residuals of gnathiid abundance regressed on sample size as a measure of gnathiid abundance corrected for sampling effort, we found that gnathiid abundance correlated positively and significantly with host size $(r=0.438, p<0.05)$. This relationship was also apparent in the analysis excluding uninfected species (16 contrasts instead of $21, r=$ $0.490, p<0.05)$. Thus gnathiid abundance covaries with fish size independently of any sampling or phylogenetic influences. 
Table 3. Abundance of gnathiid isopod larvae on elasmobranchs sampled at Moreton Bay and Heron Island, Australia, between April and August 1996

\begin{tabular}{|c|c|c|c|c|c|c|c|c|}
\hline \multirow[t]{2}{*}{ Family } & \multirow[t]{2}{*}{ Species } & \multirow[t]{2}{*}{ Location } & \multirow[t]{2}{*}{ Date } & \multicolumn{2}{|c|}{$\begin{array}{l}\text { No. of gnathiids } \\
\text { per fish }\end{array}$} & \multicolumn{2}{|c|}{$\begin{array}{l}\text { Length of host } \\
\qquad(\mathrm{cm})\end{array}$} & \multirow[t]{2}{*}{$\mathrm{n}$} \\
\hline & & & & Mean & SE & Mean & SE & \\
\hline Dasyatididae & $\begin{array}{l}\text { Dasyatis kuhlii } \\
\text { Himantura fai }\end{array}$ & $\begin{array}{l}\text { MB } \\
\text { Heron }\end{array}$ & $\begin{array}{l}\text { Jun } 96 \\
\text { Jul } 96\end{array}$ & $\begin{array}{r}6 \\
>200\end{array}$ & - & $\begin{array}{l}31 \\
84.2\end{array}$ & $\overline{3.2}$ & $\begin{array}{l}1 \\
2\end{array}$ \\
\hline Hemiscyllidae & $\begin{array}{l}\text { Hemiscyllium ocellatum } \\
\text { H. ocellatum }\end{array}$ & $\begin{array}{l}\text { Heron } \\
\text { Heron }\end{array}$ & $\begin{array}{l}\text { Apr } 96 \\
\text { Jul } 96\end{array}$ & $\begin{array}{l}3.5 \\
1\end{array}$ & $\begin{array}{l}0.5 \\
-\end{array}$ & $\begin{array}{l}40.5 \\
39\end{array}$ & $\begin{array}{l}0.5 \\
-\end{array}$ & $\begin{array}{l}2 \\
1\end{array}$ \\
\hline Brachaeluridae & Chiloscyllium punctatum & Heron & Jul 96 & $>100$ & - & 93.5 & - & 1 \\
\hline Orectolobidae & $\begin{array}{l}\text { Orectolobus ornatus } \\
\text { O. ornatus }\end{array}$ & $\begin{array}{l}\text { Heron } \\
\text { Heron }\end{array}$ & $\begin{array}{l}\text { Jul } 96 \\
\text { Aug } 96\end{array}$ & $\begin{array}{l}>75 \\
>50\end{array}$ & - & $\begin{array}{l}87 \\
93\end{array}$ & - & $\begin{array}{l}1 \\
1\end{array}$ \\
\hline Rhinobatidae & $\begin{array}{l}\text { Rhynobatus typus } \\
\text { R. typus }\end{array}$ & $\begin{array}{l}\text { MB } \\
\text { Heron }\end{array}$ & $\begin{array}{c}\text { May } 96 \\
\text { Jul } 96\end{array}$ & $\begin{array}{r}17.5 \\
1.7\end{array}$ & $\begin{array}{r}16.5 \\
0.7\end{array}$ & $\begin{array}{l}65 \\
54.5\end{array}$ & $\begin{array}{l}15 \\
6.7\end{array}$ & $\begin{array}{l}2 \\
3\end{array}$ \\
\hline Rhynchobatidae & Rhynchobatus djiddensis & Heron & Jul 96 & $>200$ & - & 126.5 & - & 1 \\
\hline
\end{tabular}

Table 4. Analysis of covariance testing for an effect of Iocation (Heron Is. and Lizard Is.) on the number of gnathinds per fish with standard length (SL) as the covariable. Data were $\log (x+1)$ transformed

\begin{tabular}{|c|c|c|c|c|c|}
\hline Speries & Source & $\mathrm{df}$ & MS & $F$ & p \\
\hline Chlorurus sordidus & $\begin{array}{c}\text { SL } \\
\text { Location }\end{array}$ & $\begin{array}{l}1 \\
1\end{array}$ & $\begin{array}{l}1.976 \\
0.327\end{array}$ & $\begin{array}{r}22.92 \\
3.80\end{array}$ & $\begin{array}{r}<0.001 \\
0.058\end{array}$ \\
\hline Ctenochaetus striatus & $\begin{array}{c}\text { SL } \\
\text { Location }\end{array}$ & $\begin{array}{l}1 \\
1\end{array}$ & $\begin{array}{l}0.833 \\
0.025\end{array}$ & $\begin{array}{r}11.36 \\
0.34\end{array}$ & $\begin{array}{l}0.002 \\
0.562\end{array}$ \\
\hline Hemigymnus melapterus & $\begin{array}{c}\mathrm{SL} \\
\text { Location }\end{array}$ & $\begin{array}{l}1 \\
1\end{array}$ & $\begin{array}{l}9.166 \\
1.554\end{array}$ & $\begin{array}{l}59.92 \\
10.16\end{array}$ & $\begin{array}{l}<0.001 \\
<0.001\end{array}$ \\
\hline Scolopsis bilineatus & $\begin{array}{c}\mathrm{SL} \\
\text { Location }\end{array}$ & $\begin{array}{l}1 \\
1\end{array}$ & $\begin{array}{l}0.379 \\
0.373\end{array}$ & $\begin{array}{l}4.03 \\
3.96\end{array}$ & $\begin{array}{l}0.051 \\
0.053\end{array}$ \\
\hline Siganus doliatus & $\begin{array}{c}\text { SL } \\
\text { Location }\end{array}$ & $\begin{array}{l}1 \\
1\end{array}$ & $\begin{array}{l}1.570 \\
1.945\end{array}$ & $\begin{array}{l}32.02 \\
39.68\end{array}$ & $\begin{array}{l}<0.001 \\
<0.001\end{array}$ \\
\hline Thalassoma lunare & $\begin{array}{c}\text { SL } \\
\text { Location }\end{array}$ & $\begin{array}{l}1 \\
1\end{array}$ & $\begin{array}{l}1.032 \\
0.378\end{array}$ & $\begin{array}{r}15.16 \\
5.56\end{array}$ & $\begin{array}{r}<0.001 \\
0.021\end{array}$ \\
\hline
\end{tabular}

\section{DISCUSSION}

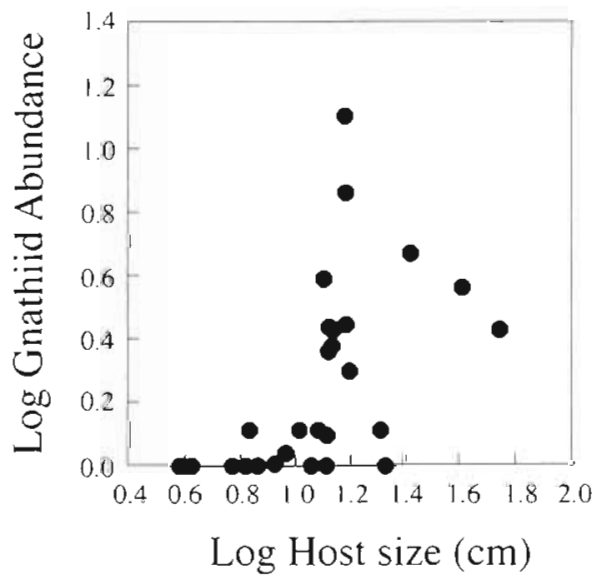

Fig. 1. Mean gnathiid abundance per host species for 29 species
Gnathiids are an important component of the parasite fauna of the tropical fishes examined. Cleaner fish, which mainly eat gnathiids (Grutter 1997a), therefore have a wide range of potential food sources. A large proportion $(70 \%)$ of the fish species examined had gnathiids. These species were from 35 genera and 20 families. No gnathiids were found on the chaetodontid species (butterfly fish), the single individual synodontid (lizard fish), and several pomacentrid species (damsel fish). Why these species had no gnathiids is unclear. The sample size for each of the chaetodontid and synodontid species was small (1 to 3 ), so a larger sample size may have detected gnathiids on these species. However, the sample sizes for the pomacentrids with no gnathiids were generally larger ( 3 to 84 ), indicating that gnathiids are indeed rare or absent on these species. 
The number of gnathiids on most fish, with the exception of some elasmobranchs, was relatively low compared to the number found to cause mortality in captive fish (Paperna \& Por 1977, Mugridge \& Stallybrass 1983). Furthermore, most gnathiids examined, except for some from elasmobranchs (Grutter unpubl. data), were also smaller $(<3.0 \mathrm{~mm})$ than the gnathiids mentioned above ( 3.3 to $5 \mathrm{~mm}$ ) that caused fish mortalities. More information on the pathological effects of small gnathiids on fish is needed to determine whether they have less of an effect on the host than do large gnathiids.

Other studies have also found gnathiids on a wide range of families from the orders (number of families) Anguilliformes (2), Beloniformes (1), Carcharhiniformes (2), Chimaeriformes (1), Coelocanthiformes (1), Gadiformes (4), Gasterosteiformes (1), Gonorhynchiformes (1), Lamniformes (1), Mugiliformes (1), Orectolobiformes (1), Ophidiiformes (2), Pleuronectiformes (2), Perciformes (22), Rajiformes (5), Salmoniformes (1), Scorpaeniformes (1), Squatiniformes (1), and Zeiformes (1) (Monod 1926, Paperna \& Por 1977, Davies 1981, Arthur 1986, Wägele 1988, Honma et al. 1991. Davies et al. 1994, Hughes 1995). In contrast they have not been found on 3 species from the order Perciformes (Kyphosidae, Labridae, and Sillaginidae) and on a species from the order Tetraodontiformes (Tetraodontidae) (Honma et al. 1991).

Host size explains some of the variation in gnathiid abundance on fish. Gnathiid numbers within a host species were correlated with host size for 5 fish species but not for the species Scolopsis bilineatus. There was a trend of more gnathiids on larger $S$. bilineatus but this was not significant, possibly due to the narrow size range of this species (compared to all other species except Ctenochaetus striatus). Similarly, among species, larger fish also had more gnathiids than smaller fish; this was true regardless of the phylogeny of the fish. The results agree with Poulin \& Rohde (1997) who found that ectoparasite abundance was correlated with fish size after controlling for phylogeny.

Several factors may affect the distribution of gnathiids among reef fish. Gnathiids may infect fish at night (Grutter unpubl. data); therefore, variation in the nocturnal habits of fish may influence their risk of infection by gnathiids. Most of the species examined are diurnal species, and little is known of their nocturnal habits. Gnathiid larvae return to the benthos to moult and all adults are non-parasitic and benthic; they therefore spend a significant proportion of their time in the benthos. Variation in the distribution of the benthic stages of gnathiids may therefore result in variation in abundance on hosts. Little is known about the distribution of gnathiids in the benthos. At Lizard Island, adult gnathiids have been found in intertidal rocks and coral; at
Heron Island they have been found in dead coral, coral, sand, and bryozoans (Cohen \& Poore 1994). More information on the distribution of the benthic stages of gnathiids is needed to determine whether it affects the distribution of the parasitic stages.

Variation in the distribution of fish may also lead to differences in gnathiid loads. Although many of the fish species examined were found in similar areas, at a smaller scale they are often restricted to particular habitats (Randall et al. 1990, Green 1996). Furthermore, their diets and foraging patterns vary greatly (Randall et al. 1990). These factors, combined with any variation in the distribution of the benthic stages of larvae, may result in different infection levels among families of fish.

Differences in the external surfaces (e.g. scales, fin structure, and mucous coatings) and microhabitats (e.g. gills, nares, eyes, vent) of fish, which may affect the feeding patterns of gnathiids, are likely to vary among families. The extent of host specificity in gnathiids is unclear. Although some species are not host specific (Monod 1926, Paperna \& Por 1977, Upton 1987), preliminary abservations suggest a degree of host specificity in larger gnathiids of some elasmobranchs which are not found on teleosts (Grutter unpubl. data).

Some fish species from Lizard Island had more gnathiids than the same fish species collected at Heron Island. This observation is reflected in the diet of cleaner fish which also contained more gnathiids at Lizard Island than at Heron Island (Grutter 1997a). However, the comparison is confounded by sampling times.

Due to the sampling regime, it was not possible to test for an effect of time. Whether gnathiid numbers change over time is uncertain. At Lizard Island, the abundance of several parasites (including gnathiids) did not differ among 3 sampling times for the species Thalassoma lunare and Hemigymnus melapterus (Grutter 1994). However, the size of gnathiids on fish varies temporally, with more small individuals being found in the winter (Grutter 1997a), suggesting some seasonality in gnathiid development. Whether this results in changes in abundance is unknown.

The host-parasite relationship between gnathiids and elasmobranchs differs. Gnathiids of elasmobranchs appear to be more strongly attached to the host than are the gnathiids of teleosts. Histopathological changes caused by gnathiids of rays (Honma \& Chiba 1991, Honma et al. 1991) are consistent with a relatively long association with the host. In contrast, Grutter (1995b) found that $50 \%$ of gnathiids from the teleost Hemigymnus melapterus left the host after capture. A longer association with a host may in part explain the higher abundance on elasmobranchs. 
Larger fish species with more parasites appear to be cleaned more; howner, when their behavior is adjusted for phylogeny, the effect of size is lost (Grutter \& Poulin 1998). In contrast, in a related study in which phylogenetic effects were not removed, individual host cleaning rates of several species increased with increasing host size and parasite load (Grutter 1995a). Whether gnathiids have an effect on cleaning behavior is unknown. Within the species Hemigymnus melapterus, individual cleaning rates increase with host size and parasite load (Grutter 1995a). Gnathiid load also increases with host size within this species (this study and Grutter 1996a), raising the possibility that gnathiids may affect cleaning behavior. Studies examining the effect of gnathiids and other parasites on client cleaning behavior are needed to resolve the relationship between gnathiid load and cleaning behavior.

Acknowledgements. Many thanks to Maria Bavins, Mark Johnson, and Ian Nielsen for their help in the field and to Howard J. Choat and Kendall Clements for collecting the fish in October, 1991. Leslie Chisholm kindly collected the rays and sharks at Heron Island and Eric Boel collected the rays at Moreton Bay. The staffs of Heron Island Research Station and Lizard Island Research Station provided much generous assistance. Robert J. G. Lester provided much logistical support and made helpful comments on an earlier version of this manuscript. This research was funded by an Australian Research Council grant to Robert J. G. Lester and A.S.G.

\section{LITERATURE CITED}

Arthur JR (1986) Parasites of juvenile milkfish. The first Asian fisheries forum. Proc 1st Asian fisheries forum, Manila, Philippines, 26-31 May 1986, p 261-264

Cohen BF, Poore GCB (1994) A phylogeny of the Gnathiidae (Crustacea: Isopoda) with descriptions of new genera and species from south-eastern Australia. Mem Mus Vic 54: $271-397$

Davies AJ (1981) A scanning electron microscope study of the praniza larva of Gnathia maxillaris Montagu (Crustacea, Isopoda, Gnathiidae), with special reference to the mouthparts. J Nat Hist 15:545-551

Davies AJ, Eiras JC, Austin RTE (1994) Investigations into the transmission of Haemogregarina bigemia Laveran and Mesnll 1901 (Apicomplexa: Adeleorina) belween intertidal fishes in Portugal. J Fish Dis 17:283-289

Felsenstein $J$ (1985) Phylogenies and the comparative method. Am Nat 125:1-15

Garland T Jr, Harvey PH, Ives AR (1992) Procedures for the analysis of comparative data using phylogenetically independent contrasts. Syst Biol 41:18-32

Gorlick DL, Atkjns PD, Losey GS (1987) Effect of cleaning by Labroides dimidiatus (Labridae) on an ectoparasite infecting a Pomacentrus vaiuli (Pomacentridae) population at Enewetak Atoll. Copeia 1987:41-45

Green AL (1996) Spatial, temporal, and ontogenetic patterns of habitat use by coral reef fishes (Family Labridae). Mar Ecol Prog Ser 133:1-11

Grutter AS (1994) Spatial and temporal variations of the ectoparasites of seven reef fish species from Lizard Island and Heron Island, Australia. Mar Ecol Prog Ser 115:21-30

Grutter AS (1995a) The relationship between cleaning rates and ectoparasite loads in coral reef fishes. Mar Ecol Prog Ser 118:51-58

Grutter AS (1995b) A comparison of methods for sampling ectoparasites from coral reef fishes. Mar Freshwat Res 46 $897-903$

Grutter AS (1996a) Parasite removal rates by the cleaner wrasse Labroides dimidiatus. Mar Ecol Prog Ser 130:61-70

Grutter AS (1996b) Experimental demonstration of no effect by the cleaner wrasse Labroides dimidiatus (Cuvier and Valenciennes) on the host fish Pomacentrus moluccensis (Bleeker). J Exp Mar Biol Ecol 196:285-298

Grutter AS (1997a) Spatio-temporal variation and feeding selectivity in the diet of the cleaner fish Labroides dimidiatus. Copeia 1997:346-355

Grutter AS (1997b) Size-selective predation by the cleaner fish Labroides dimidiatus. J Fish Biol 50:1303-1308

Grutter AS (1997c) The effect of cleaner fish Labroides dimidiatus on the abundance and species composition of coral reef fish. Oecologia 111:137-143

Grutter AS, Poulin R (1998) Cleaning of coral reef fishes by the wrasse Labroides dimidiatus: ecological and phylogenetic influences. Copeia 1998:120-127

Harvey PH, Pagel MD (1991) The comparative method in evolutionary biology. Oxford University Press, Oxford

Honma Y, Chiba A (1991) Pathological changes in the branchial chamber wall of stingrays, Dasyatis spp., associated with the presence of juvenile gnathiids (Isopoda, Crustacea). Gyobyo Kenkyu 26(1):9-16

Honma Y, Tsunaki S, Chiba A, Ho J (1991) Histopathological studies on the juvenile gnathiid (Isopoda, Crustacea) parasitic on the branchial chamber wall of the stingray, Dasyatus akajei, in the Sea of Japan. Rep Sado Mar Biol Stn, Niigata Univ 21:37-47

Hughes GM (1995) The gills of the coelacanth, Latimeria chalumnae, a study in relation to body size. Phil Trans $\mathrm{R}$ Soc Lond B Biol Sci 347(1322):427-438

Klitgaard AB (1991) Gnathia abyssorum (G.O. Sars, 1872) (Crustacea, Isopoda) associated with sponges. Sarsia 76 (1/2):33-40

Lester RJG, Sewell KB (1989) Checklist of parasites from Heron Island, Great Barrier Reef. Aust J Zool 37:101-128

Losey GS (1972) The ecological importance of cleaning symbiosis. Copeia 1972:820-833

Losey GS (1987) Cleaning symbiosis. Symbiosis 4:229-258

Monod I (1926) Les Gnathiidae. Essai monographique (morphologie, biologie, systématique). Mem Soc Sci Nat Maroc 13:1-668

Mugridge RER, Stallybrass HG (1983) A mortality of eels, Anguilla anguilla L., attributed to Gnathiidae. J Fish Biol 6:81-82

Nelson JS (1994) Fishes of the world, 3rd edn. John Wiley \& Sons, New York

Pagel MD (1992) A method for the analysis of comparative data. J Theor Biol 156:431-442

Paperna I, Por FD (1977) Preliminary data on the Gnathiidae (Isopoda) of the Northern Red Sea, the Bitter Lakes, and the Mediterranean and the biology of Gnathia piscivora n. sp. Rapp P-V Reun Comm Int Explor Sci Mer Medit 24(4): 195-197

Poulin R (1996) Measuring parasite aggregation: defending the index of discrepancy. Int J Parasitol 26:227-229

Poulin R, Rohde K (1997) Comparing the richness of metazoan ectoparasite communities of marine fishes: controlling for host phylogeny. Oecologia 110:278-283 
Purvis A, Gittleman JL, Luh HK (1994). Truth or consequences: effects of phylogenetic accuracy on two comparative methods. J Theor Biol 167:293-300

Purvis A, Rambaut A (1994) Comparative analysis by independent contrasts (CAIC), version 2.0. Oxford University

Randall JE, Allen GR, Steene RC (1990) Fishes of the Great Barrier Reef and Coral Sea. Crawford House Press, Bathurst, NSW

Upton NPD (1987) Asynchronous male and female life cycles

Editorial responsibility: Charles Birkeland (Contributing Editor), Mangilao, Guam in the sexually dimorphic, harem-forming isopod Paragnathia formica (Crustacea: Isopoda). J Zool Lond 212 $677-690$

Wägele JW (1988) Aspects of the life-cycle of the Antarctic fish parasite Gnathia calva Vanhöfen (Crustacea: Isopoda). Polar Biol 8:287-291

Youngbluth MJ (1968) Aspects of the ecology and ethology of the cleaning fish, Labroides phthirophagus Randall Z Tierpsychol 25(8):915-932

Submitted: June 9, 1997; Accepted: December 17, 1997 Proofs received from author(s): March 17, 1998 